\title{
Efficacy Testing of Orally Administered Praziquantel to Common Carp Naturally Infected by Caryophyllidean Tapeworms (Platyhelminthes: Eucestoda)
}

\author{
Eliška Sudová1, Veronika Piačková ${ }^{1}$, Josef Velíšek ${ }^{1}$, Martin Pijáček², Zdeňka Svobodová1,2 \\ ${ }^{1}$ University of South Bohemia in České Budějovice, Faculty of Fisheries and Protection of Waters, South \\ Bohemian Research Center of Aquaculture and Biodiversity of Hydrocenoses and Research Institute of Fish \\ Culture and Hydrobiology, Vodňany, Czech Republic \\ ${ }^{2}$ University of Veterinary and Pharmaceutical Sciences, Brno, Czech Republic
}

Received April 3, 2009

Accepted April 6, 2010

\begin{abstract}
The aim of the study was to assess the effects of orally applied praziquantel on the treatment efficacy against most abundant tapeworms (Atractolytocestus huronensis Anthony, 1958 and Khawia sinensis Hsü, 1935) of common carp (Cyprinus carpio Linnaeus). Naturally infected fish (1.5-yearold; $\mathrm{K}_{1-2}$ ) were divided into 6 groups. Three trial groups were administered praziquantel mixed in heat-treated amyloid vehicle (at doses of $50 \mathrm{mg} \cdot \mathrm{kg}^{-1}$ body weight). In 3 groups of control, the fish were administered amyloid vehicle only. Fish were examined using gut dissection 2, 4 and 6 days after the administration. The location, intensity and prevalence of individual species of tapeworms were recorded. A. huronensis and $K$. sinensis were found in the gut of carp together. A. huronensis was situated in the oesophageal part of foregut, and $K$. sinensis came after - immediately before the first intestine loop, of the intestines of carp. The invasion of $A$. huronensis was fully eliminated in all trial groups after 4 days whereas some specimens of $K$. sinensis still persisted in the gut of few fish. The full elimination of both parasites was observed 6 days after administration. Our results showed that elimination of $K$. sinensis takes longer than elimination of $A$. huronensis. The dose of $50 \mathrm{mg}^{\mathrm{kg}} \mathrm{kg}^{-1}$ of orally administered praziquantel is effectual to control A. huronensis and $K$. sinensis infections in common carp successfully, however, a significant decrease of the number of parasites was also caused by a single oral administration of big bolus vehicle and leaving unfed fish in the clean water.
\end{abstract}

Khawia sinensis, Atractolytocestus huronensis, Cyprinus carpio, treatment, anthelmintic

Fish tapeworms are widespread throughout all major water systems of Europe and demonstrate a high degree of host specificity. Some of these parasites could cause disease and death in carp in aquaculture settings and may retard growth in hatchery-reared common carp (Cyprinus carpio L.). Other consequences include dysfunction or destruction of the intestinal lining and adverse changes to certain blood indicators (Niemczuk 1991; Molnár et al. 2003). There are two species of tapeworms from the order Caryophyllidea frequently found in the intestine of South Bohemian carp.

The older known species is Khawia sinensis Hsü, 1935. It is the easily identified carp tapeworm whose biology and developmental cycle is described in detail by various authors (Kulakovskaya 1963; Demshin and Dvoryadkin 1980; Scholz 1991). The range of the parasite has extended greatly, despite legal prohibition of the introduction and movement of infected fish in the end of $20^{\text {th }}$ century (Yeomans et al. 1997).

The second relatively new species is Atractolytocestus huronensis. This parasite was first described by Anthony (1958) in North America. Now, it is an important endoparasite in the intestine of common carp, Cyprinus carpio L. reared in ponds in the Czech Republic. During the last decades, this parasite has spread across Europe. Occurrence of this tapeworm was recorded in England (Chubb et al. 1996), Czech Republic and Hungary (Molnár et al. 2003; Majoros et al. 2003), Slovakia (Oros et al. 2004) and Germany (Kappe et al. 2006). Scholz et al. (2001) noted the occurrence of $A$. sagittata, very close species, in the intestine of $C$. carpio from Japan. Other dispersion could be assumed with regard to progressive export of parasitized carp to many other countries. The prevalence of infection

Address for correspondence:

MVDr. Eliška Sudová, PhD.

University of South Bohemia České Budějovice

Research Institute of Fish Culture and Hydrobiology

Zátiší 728/II, 38925 Vodňany, Czech Republic

Phone: +420387774623

Fax: + 420387774634

E-mail: sudova@vurh.jcu.cz

http://www.vfu.cz/acta-vet/actavet.htm 
may reach $100 \%$ in intensive and semi-intensive pond culture systems, where the parasite is a particular threat to underyearling carp. Pathology caused by A. huronensis is described in detail by Molnár et al. (2003), who pointed out the potential of higher pathogenicity of A. huronensis in comparison with Bothriocephalus acheilognathi.

Eradication of fish tapeworms is problematic. Intensive production of fish has inevitably created a requirement for medicines, but the legislative framework in the European Union (EU) has made it uneconomic for pharmaceutical companies to develop medicines for a small market (Treves-Brown 1999). Therefore, the limited possibility of using chemicals and drugs for treatment makes the situation even more difficult to handle. Many veterinarians try to use chemicals with a potential effect on fish tapeworm, but hardly anybody knows exactly the consequent effect. Various chemicals including praziquantel, benzimidazoles and niclosamides are recommended for oral treatment of fish tapeworms (Treves-Brown 2000), however, there are no determined maximum residue limits (MRL) in fish for these substances, which means the maximum level of a chemical which is permitted to be present in a human food, expressed in milligrams of the chemical per kilogram of the food $\left(\mathrm{mg} \cdot \mathrm{kg}^{-1}\right)$ unless otherwise stated. That is why, the most perspective praziquantel is allowed to use only for ornamental and non-food fish, and for food fish treatment it is still under experimental studies such as this one. Nevertheless, the development of a tapeworm eradication procedure is necessary for continued interstate shipment of tapeworm-free fish (Mitchell 2004) and economical profitable of fish growth rate. The aim of the present study was to determine location, intensity and prevalence of individual species of fish tapeworms before and after praziquantel treatment.

\section{Materials and Methods}

Individuals of 1.5-year-old carp $\left(\mathrm{K}_{1-2}\right)$ weighing $272 \pm 50 \mathrm{~g}$ naturally infected by tapeworms were obtained from commercial producer. The fish were acclimated to $20 \pm 2{ }^{\circ} \mathrm{C}$ for 3 days prior to the experiment and were not fed throughout the trial. The presence and numbers of tapeworms in the intestine were confirmed by examination of 15 fish and the results from this initial examination were used as starting values for final evaluation. A total of 108 carp intended for test were divided into 6 groups consisting of 6 fish per tank and each group was replicated three times. The volume of each experimental tank was 2501 and water from each tank was changed daily. All used tanks were aerated with an air pump attached to aeration stones and oxygen saturation and $\mathrm{pH}$ were measured every day. Oxygen saturation of water was above $80 \%$ (ranging from $72 \%$ to $91 \%$ ) and $\mathrm{pH}$ ranged from 6.28 to 7.30 .

Trial

Fish from 3 trial groups were intubated directly into the oesophagus with the drug mixed into a heat-treated amyloid vehicle at a dose of $5 \mathrm{ml} \cdot \mathrm{kg}^{-1}$ body weight. The concentration of praziquantel was $50 \mathrm{mg} \cdot \mathrm{kg}^{-1} \mathrm{bw}$. The vehicle was prepared by heating $60 \mathrm{~g}$ food starch (Solamyl) in 11 water to $100{ }^{\circ} \mathrm{C}$ temperature. In 3 control groups, the fish were administered amyloid vehicle in the same dose only. The fish were subsequently observed in the recovery tanks for any signs of regurgitation of anthelmintics. Tapeworm survival in common carp was determined 2, 4 and 6 days after administration (control and trial group in each time together). Fish were killed with a blow on the head, the visceral cavity was cut open and intact intestinal tracts were removed and examined for tapeworms. The effectiveness of treatment for both species of tapeworms was confirmed by comparison of the number of parasites with those in the control at the same examination time. The location, intensity, prevalence and the time of elimination of tapeworms were recorded.

\footnotetext{
Statistical analysis

Statistical analysis was carried out using STATISTICA software 8.0 for Windows (StatSoft, Prague, Czech Republic).

The prevalence of tapeworms was represented in percentage and thus had to be subjected to arcsin transformation prior to any further processing. Data were first tested for normality (Kolmogorov Smirnov test) and homoscedasticity of variance (Bartlett's test). If those conditions were satisfied, two-way analysis of variance (ANOVA) was used to determine if there were any significant differences in measured variables among control and trial groups.
}

\section{Results and Discussion}

No clinical abnormalities were observed in the fish treated with praziquantel. Praziquantel and heat-treated amyloid vehicle were well tolerated by the fish and no fish were lost during the experiment. 
Two species of tapeworms, Atractolytocestus huronensis and Khawia sinensis, were found in the gut of examined carp concurrently. Both species of tapeworms have their specific position of occurrence in the intestine. A. huronensis was situated in the oesophageal part of foregut. This part of the intestine is characterised by the presence of numerous intestinal crypts located close to one another, in addition to intestinal folds generally typical of the gut of cyprinids. $K$. sinensis came after - immediately before the first intestine loop, of the gut of carp (Plate I, Fig. 1). Scholz et al. (1990) described the location of K. sinensis and found the parasite in all parts of the gut; however, the position of the majority of parasites (73\%) from their study corresponded with our findings. The location of attachment of $A$. huronensis is described by various authors, who pointed out the presence of tapeworms in the foregut, often in the most proximal 3 to $5 \mathrm{~cm}$ segment thereof (Molnár et al. 2003; Majoros et al. 2003; Williams 2008). There are no data available on the presence of both tapeworms together in the gut of fish.

The intensity of infestation of $A$. huronensis and $K$. sinensis was very variable depending on individuality of each fish, however, the mean intensity of both tapeworms continually decreased in control and trial groups during the trial time. The number of A. huronensis decreased more rapidly then the number of $K$. sinensis in praziqantel-treated groups. There were no tapeworms $A$. huronensis found in the intestine of praziqantel-treated carp four days after application while the decreasing trend of $K$. sinensis was still continuing. The intestines of treated fish were free from both tapeworms 6 days after treatment (Table 1). Molnár et al. (2003) observed that species A. huronensis may have a more important pathological role than $K$. sinensis because of $A$. huronensis rather securely attaches itself to the intestinal epithelium and can be removed from there only with difficulty. This is in contrast with our findings. We observed easy and more rapid elimination of $A$. huronensis than $K$. sinensis in control and praziquantel-treated groups.

Table 1. Survey of carp (Cyprinus carpio $-\mathrm{K}_{1-2}$ ) examined during the trial and their infestation with tapeworms

\begin{tabular}{|l|c|c|c|c|c|c|c|c|}
\hline \multirow{2}{*}{$\begin{array}{l}\text { Group } \\
\text { of fish }\end{array}$} & \multirow{2}{*}{$\begin{array}{c}\text { Trial time } \\
\text { (day) }\end{array}$} & $\begin{array}{c}\text { Name } \\
\text { of group }\end{array}$ & examined & $\begin{array}{c}\text { infested by } \\
\text { A. huronensis }\end{array}$ & $\begin{array}{c}\text { infested by } \\
\text { K. sinensis }\end{array}$ & $\begin{array}{c}\text { No. of } \\
\text { tapeworms } \\
\text { A. huronensis/ } \\
\text { K. sinensis }\end{array}$ & $\begin{array}{c}\text { Mean intensity } \\
\text { of } A \text {. huronensis } \\
\text { (min.-max.) }\end{array}$ & $\begin{array}{c}\text { Mean intensity } \\
\text { of } K \text {. sinensis } \\
\text { (min.-max.) }\end{array}$ \\
\hline Pretrial & - & C 0 & 15 & 15 & 8 & $797 / 38$ & $53(1-184)$ & $5(2-18)$ \\
\hline Control & 2 & C 2 & 18 & 14 & 6 & $122 / 25$ & $9(1-29)$ & $4(2-10)$ \\
\hline Trial & 2 & T 2 & 18 & 6 & 5 & $10 / 8$ & $2(1-3)$ & $2(1-2)$ \\
\hline Control & 4 & C 4 & 18 & 8 & 5 & $131 / 15$ & $19(2-83)$ & $3(2-5)$ \\
\hline Trial & 4 & T 4 & 18 & - & 2 & $-/ 2$ & - & $1(1)$ \\
\hline Control & 6 & C 6 & 18 & 4 & 7 & $27 / 20$ & $7(2-11)$ & $3(1-9)$ \\
\hline Trial & 6 & T 6 & 18 & - & - & $-/-$ & & - \\
\hline
\end{tabular}

Scholz et al. (1991) described the effect of starvation of the infected carp for survival of the parasite. The burden in fed fish, in his trial, was conspicuously higher than in carp without feed and the greatest number of tapeworms was expelled from fish between day 3 and 10 of the experiment. In our study, we observed the main marked elimination of tapeworms between days 3 and 5 of starvation in all groups. An apparently higher number of tapeworms and their remnants were recorded in the sediment of treated fish than in the sediment of control fish. However, the exact number of expelled tapeworms was not calculated due to probable decomposition of tapeworms in the gut and thus difficult detection in the sediment. Yellow coloured remains of tapeworms were infrequently observed in the caudal portion of intestine of fish in all groups. 


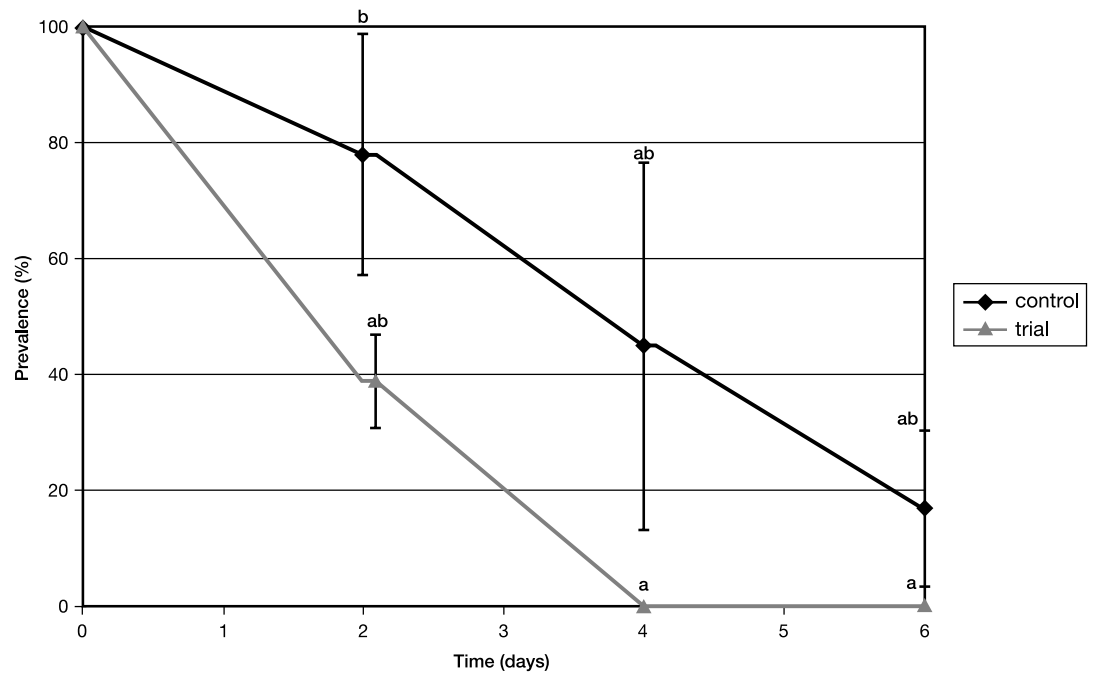

Fig. 2. Prevalence of Atractolytocestus huronensis

Groups with different alphabetic superscripts differ significantly at $p<0.05$ or $p<0.01$

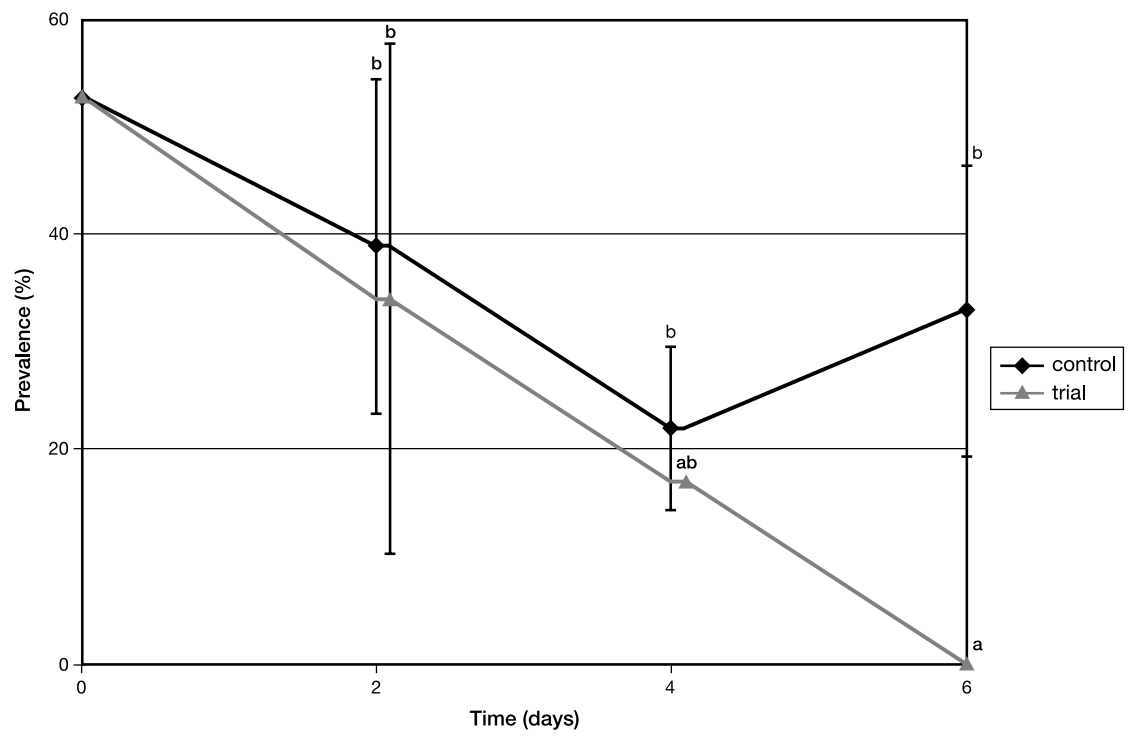

Fig. 3. Prevalence of Khawia sinensis

Groups with different alphabetic superscripts differ significantly at $p<0.05$ or $p<0.01$

The prevalence of $A$. huronensis and $K$. sinensis was $100 \%$ and $60 \%$, respectively, in fish checked before the experiment began $(\mathrm{C} 0)$. The statistical evaluation was made with the results obtained after application of praziquantel and initial values were used only in figures in time zero. We observed a mild effect of praziquantel on the prevalence of $A$. huronensis. The trial groups did not differ from control groups in the same time of examination, whereas a significantly lower prevalence of A. huronensis $(p<0.01)$ was 
observed in trial groups T4 and T6 compared to control group C2 (Fig. 2). We assume that the small differences between the control and trial groups could be caused by the high willingness of $A$. huronensis to be expelled due to starvation.

The substantial effect of praziquantel was observed on the tapeworm $K$. sinensis (Fig. 3). The prevalence in trial group (T6) was significantly lower $(p<0.05)$ compared to control group (C6). Decreasing values of prevalence $(p<0.05)$ were also noticed in the trial groups $\mathrm{T} 2$ and T6. These results point out the potential of praziquantel to eliminate or completely exterminate the tapeworms $K$. sinensis.

There are no data available for the effectual doses of orally administered praziquantel. Our results indicate that the dose of $50 \mathrm{mg} \cdot \mathrm{kg}^{-1}$ of orally administered praziquantel is effectual to control $K$. sinensis and A. huronensis infections in common carp successfully, however, a significant decrease of the number of parasites was also caused by a single oral administration of big bolus vehicle and leaving unfed fish in the clean water.

\section{Účinek perorálně podávaného praziquantelu na kapra obecného infikovaného tasemnicemi z řádu Caryophyllidea (Platyhelminthes: Eucestoda)}

Cílem práce bylo posoudit účinnost orálně podávaného praziquantelu na nejčastěji se vyskytující tasemnice (Atractolytocestus huronensis Anthony, 1958 a Khawia sinensis Hsü, 1935) kapra obecného (Cyprinus carpio L.). Rok a půl staré infikované ryby $\left(\mathrm{K}_{1-2}\right)$ byly rozděleny do 6 skupin. Pokusným skupinám (3 skupiny) byl jícnovou sondou aplikován praziquantel rozpuštěný ve škrobovém vehikulu v dávce $50 \mathrm{mg} \mathrm{kg}^{-1}$ živé váhy. Kontrolním skupinám ryb (3 skupiny) bylo aplikováno jen čisté škrobové vehikulum. Ryby byly vyšetrovány 2, 4 a 6 dní po aplikaci a byla zaznamenávána intenzita, prevalence a lokalizace jednotlivých druhů tasemnic. Ve střevech byly nalezeny současně tasemnice $A$. huronensis a $K$. sinensis. Tasemnice $A$. huronensis se nacházely v jícnové části předního střeva a tasemnice $K$. sinensis byly lokalizovány více kaudálně - bezprostředně před první stř̌evní kličkou. Infekce $A$. huronensis byla 4 . den u všech ryb z pokusných skupin plně eliminována, zatímco invaze tasemnic $K$. sinensis stále přetrvávala. K úplné eliminaci obou druhů tasemnic došlo 6 dní po aplikaci praziquantelu. Podle výsledků je zřejmé, že eliminace $K$. sinensis trvá delší dobu než eliminace $A$. huronensis. Dávka $50 \mathrm{mg} \cdot \mathrm{kg}^{-1}$ orálně podávaného praziquantelu je účinná proti tasemnicím $A$. huronensis a $K$. sinensis, avšak je prokazatelné, že významný pokles počtu parazitů byl způsoben také jednorázovou aplikací velkého sousta škrobu do jícnu a ponecháním nekrmených ryb v čisté vodě.

\section{Acknowledgement}

This research was supported by the Ministry of Education, Youth and Sports of the Czech Republic (Grants no. MSM 6007665809 and MSM 6215712402 ), and the Ministry of Agriculture of the Czech Republic (Grant no. QH71305). Also thanks to project CENAKVA (CZ.1.05/2.1.00/01.0024).

\section{References}

Anthony JD 1958: Atractolytocestus huronensis n. gen., n. sp. (Cestoda: Lytocestidae) with notes on its morphology. Trans Amer Microscop Soc 77: 383-390

Chubb JC, Kirk R, Wellby I 1996: Caryophyllaeid tapeworm Atractolytocestus huronensis Anthony, 1958 (= Markevitschia sagittata Kulakovskaya \& Akhmerov, 1965) in carp Cyprinus carpio L. in British Isles - another translocation. Abstract of the British Society for Parasitology Spring Meeting, 1-3 April, University of Wales, Bangor, p. 66

Demshin NI, Dvoryadkin VA 1980: Biology of Khawia sinensis Hsü, 1935 (Caryophyllidea, Cestoda) - a parasite of amur carp (In Russian). Gidrobiol Zh 16: 77-82

Kappe A, Seifert T, El-Nobi G, Brauer G 2006: Occurrence of Atractolytocestus huronensis (Cestoda, Caryophyllaeidae) in German pond-farmed common carp Cyprinus carpio. Dis Aquat Organ 70: 255-259

Kulakovskaya OP 1963: On the biology and distribution of the tapeworm Khavia [sic] sinensis Hsü, 1935. Probl Parazitologii 2: 200-205 (In Russian)

Majoros G, Csaba G, Molnár K 2003: Occurrence of Atractolytocestus huronensis Anthony, 1958 (Cestoda: Caryophyllaeidae), in Hungarian pond-farmed common carp. Bull Eur Ass Fish Pathol 23: 167-175 
Mitchell AJ 2004: Effectiveness of praziquantel bath treatments against Bothriocephalus acheilognathi in grass carp. J Aquat Anim Health 16: 130-136

Molnár K, Majoros G, Csaba Gy, Székely Cs 2003: Pathology of Atractolytocestus huronensis Anthony, 1958 (Cestoda: Caryophyllaeidae) in Hungarian pond-farmed common carp. Acta Parasitol 48: 222-228

Niemczuk W 1991 Histological and histochemical-enzymatic changes in the internal organs of carp infected with the cestodes Khawia sinensls or Bothriocephalus acheilognathi. Zesz Nauk Akad Rolniczej Wroclawiu. Weterynaria 47: 21-42 (In Polish)

Oros M, Hanzelová V, Scholz T 2004: The cestode Atractolytocestus huronensis (Caryophyllidea) continues to spread in Europe: new data on the helminth parasite of the common carp. Dis Aquat Organ 62: 115-119

Scholz T 1991: Development of Khawia sinensis Hsü, 1935 (Cestoda: Caryophyllidea) in the fish host. Folia Parasitol 38: 225-234

Scholz T, Shimazu T, Olson PD, Nagasawa K 2001: Caryophyllidean tapeworms (Platyhelminthes: Eucestoda) from freshwater fishes in Japan. Folia Parasitol 48: 275-288

Scholz T, Špeta V, Zajíček J 1990: Life history of the tapeworm Khawia sinensis Hsü, 1935, a carp parasite, in the pond Drážský Skaličany near Blatná, Czechoslovakia. Acta Vet Brno 59: 51-63

Treves-Brown KM 1999: Availability of medicines for fish. Fish Vet J 4: 40-55

Treves-Brown KM 2000: Applied Fish Pharmacology. Kluwer Academic Publishers, London, 309 p.

Williams CF 2008: Impact assessment of non-native parasites in freshwater fisheries in England and Wales: doctoral thesis. University of Stirling, Scotland, UK, 340 p.

Yeomans WE, Chubb JC, Sweeting RA 1997: Khawia sinensis (Cestoda: Caryophyllidea) - an indicator of legislative failure to protect freshwater habitats in the British Isles? J Fish Biol 51: 880-885 
Plate I

Sudová E. et al.: Efficacy Testing ... pp. S73-S78

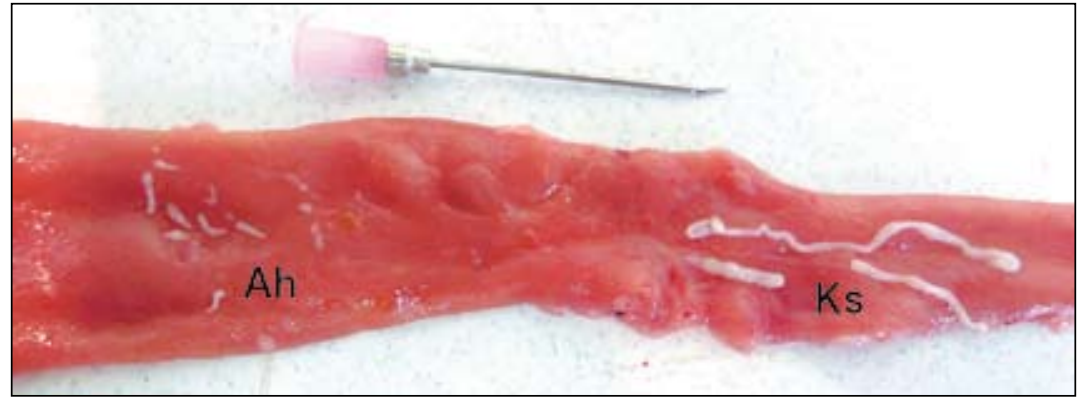

Fig. 1. Occurrence and position of tapeworms in the intestine of carp (Cyprinus carpio L.) $\mathrm{Ah}$ - Atractolytocestus huronensis, Ks - Khawia sinensis 